\title{
Formaldehyde induced anti-N: a possible cause of renal graft failure
}

\author{
D. W. GORST, R. A. RICHES, AND P. H. RENTON \\ From the National Blood Transfusion Service, Roby Street, Manchester M1 3BP, UK
}

SUMMARY Treatment of human red cells with low concentrations of formaldehyde induces an antigenic change which makes them react very strongly with the anti-N sera found in certain patients treated by haemodialysis. This supports the idea that formaldehyde sterilisation of reusable home dialysers leads to the development of anti-N in these patients' sera. The clinical problems produced by this antibody are discussed together with ways of overcoming them.

The blood group antibody, anti-N, is rare in human sera, but Howell and Perkins (1972) observed 12 examples in 416 renal failure patients maintained on chronic haemodialysis. Harrison et al. (1975) also observed anti-N in 15 out of 33 home dialysis patients, and in the present study 20 examples of the antibody were found among 95 sera from such patients. Unlike the anti-N occasionally found in other sera, which tend to be rather weak and active only at low temperatures, the majority of these antiNs are powerful agglutinins, often active at $37^{\circ} \mathrm{C}$. These antibodies lead to difficulty in providing compatible blood for the occasional transfusion which these patients require, but more important than this is the strong probability of their interfering with the function of a transplanted kidney. Donor kidneys are commonly refrigerated before transplantation, and if they come from $\mathrm{N}$ or $\mathrm{MN}$ donors it seems inevitable that donor erythrocytes, which must still be present in the renal capillaries even though the kidney has been flushed with saline, will be agglutinated by the anti- $\mathrm{N}$ in the recipient's serum, resulting in capillary blockage and interference with the function of the kidney. At least one recorded episode of graft failure was probably due to this phenomenon (Belzer et al., 1971). The renal damage caused by the anti-N could be to some extent reduced by warming the kidney before transplantation, but this is an undesirable procedure liable itself to lead to reduced viability. These considerations indicate that it is important to discover the cause of the anti-N in these patients' sera and, if possible, to prevent its development.

Howell and Perkins (1972) suggested a number of

Received for publication 24 March 1977 possibilities, one of which was that formaldehyde used to sterilise reusable dialysers might lead to an antigenic change in the $\mathrm{N}$ antigen of patients' erythrocytes, and they observed that red cells in small amounts were frequently left behind in the dialyser. The suggestion that formaldehyde might be responsible was supported by Harrison et al. (1975), who observed anti-N in 15 out of 33 patients maintained on home dialysis with reusable dialysers sterilised by formaldehyde but found no antibodies in 28 patients treated in hospital with disposable dialysers. We have found that treatment of erythrocytes with certain concentrations of formaldehyde does indeed induce a change which causes them to react very strongly with the anti-N in the sera of these patients. This indicates that the use of formaldehyde to sterilise the dialysers is almost certainly the factor which causes the anti-N to appear.

\section{Material and methods}

Blood specimens were obtained from patients undergoing home dialysis under the care of the University Hospital of South Manchester Artificial Kidney Unit. The initial screening of $\mathbf{9 5}$ sera for cold agglutinins was carried out at the hospital: the specimens containing anti- $\mathrm{N}$ were referred to the Blood Transfusion Centre for further study.

The MN types of the blood specimens were determined by use of Blood Group Reference Laboratory rabbit antisera and human typing sera. The separated sera were stored at $-20^{\circ} \mathrm{C}$ until tested.

The dialysers in use are of the Kiil type, and the sterilising agent used between dialysis runs is $2 \% \mathrm{w} / \mathrm{v}$ formaldehyde solution, which remains in contact with the dialysis membranes for up to 48 hours. 
Membranes are used three times but connecting tubing only once.

Twenty anti- $\mathrm{N}$ sera were investigated using formaldehyde treated red cells. The tests for agglutination were all carried out on slides at room temperature. The results were read microscopically after six minutes. Absorptions were carried out at $20-22^{\circ} \mathrm{C}$ for 30-minute periods and eluates were made by heating the cells to $60^{\circ} \mathrm{C}$ followed by rapid centrifugation. Electrophoretic mobility was measured by the method of Bangham et al. (1958).

Normal group $\mathbf{O}, \mathrm{M}$ and $\mathrm{N}$ cells were obtained from the fully typed donor panel in current use.

After preliminary experiments with various times, temperatures, and concentrations, red cells were treated with formaldehyde by mixing 1 volume of washed packed cells with 10 volumes of formalin $(40 \% \mathrm{w} / \mathrm{v})$ diluted in saline to a concentration of $0.06 \%$ formaldehyde. After incubation for 20 hours at room temperature the cells were washed four times in saline.

\section{Results}

Treatment of cells with 10 volumes of $0.06 \%$ formaldehyde for $\mathbf{2 0}$ hours at room temperature is found to have a striking effect on the agglutinability by renal dialysis anti-N sera. The strength of reaction and titre with $\mathbf{N}$ cells are greatly increased and even $\mathbf{M}$ cells become strongly agglutinable.

These effects are illustrated in Table 1, which also shows that formaldehyde induces a new specificity in cells, which may be called $N_{F}$. In this table some of the reactions of a renal dialysis anti- $\mathrm{N}$, some other anti- $\mathrm{N}$ reagents, and some anti-M reagents with cells treated by formaldehyde and by papain are shown. Formaldehyde treatment of cells greatly increases the titre with the renal dialysis serum but reduces or abolishes the reactions with other types of anti-N and
anti-M reagents. Furthermore, although formaldehyde treated $\mathbf{N}$ cells react to a higher titre than formaldehyde treated $\mathbf{M}$ cells with renal dialysis anti$\mathrm{N}$ serum, the difference is abolished by treatment with papain which, as is well known, destroys the $M$ and $\mathbf{N}$ antigens. In addition to the results shown in Table 1 , similar results were obtained with a further 19 renal dialysis anti- $\mathrm{N}$ sera, and one other non-renal anti-N, and the formaldehyde treated cells failed to react with 50 normal human sera without antibodies. It might be thought from these results that the anti$\mathrm{N}_{\mathrm{F}}$ had no connection with the anti- $\mathrm{N}$ in the renal dialysis sera, and this was also suggested by the fact that it was possible to remove the anti-N from such sera by a single absorption with $\mathbf{N}$ cells (or $\mathbf{M}$ cells), leaving anti- $\mathrm{N}_{F}$ behind; further absorptions caused no reduction of titre of the anti- $\mathrm{N}_{\mathrm{F}}$. On the other hand, four absorptions with formaldehyde treated $\mathbf{M}$ cells removed all antibody. However, an eluate from $\mathrm{N}$ cells treated with renal dialysis anti- $\mathrm{N}$ reacted more strongly with formaldehyde treated $\mathbf{M}$ and $\mathbf{N}$ cells than with untreated $N$, a pattern of reaction clearly distinguishing the renal dialysis anti- $\mathrm{N}$ from the anti$\mathbf{N}$ in other human and rabbit sera. Furthermore, strong reactions with formaldehyde treated cells were obtained with all of 20 renal dialysis sera containing anti-N but with none of seven renal dialysis sera not containing anti-N. This shows that the anti$\mathrm{N}$ is part of the response of the patient to formaldehyde treated cells.

Treatment of cells by trypsin or neuraminidase did not abolish the formaldehyde change. The electrophoretic mobility of the altered cells was normal, and so was the surface charge, as shown by agglutination with $0.05 \%$ polybrene (Bird and Wingham, 1973).

The action of formaldehyde in inducing $N_{F}$ specificity in red cells is markedly temperature dependent. At a concentration of $0.06 \%$, formaldehyde had a detectable effect after only 30 seconds at $37^{\circ} \mathrm{C}$ but

Table 1 Reactions of anti-N and anti-M reagents with $M$ and $N$ red cells

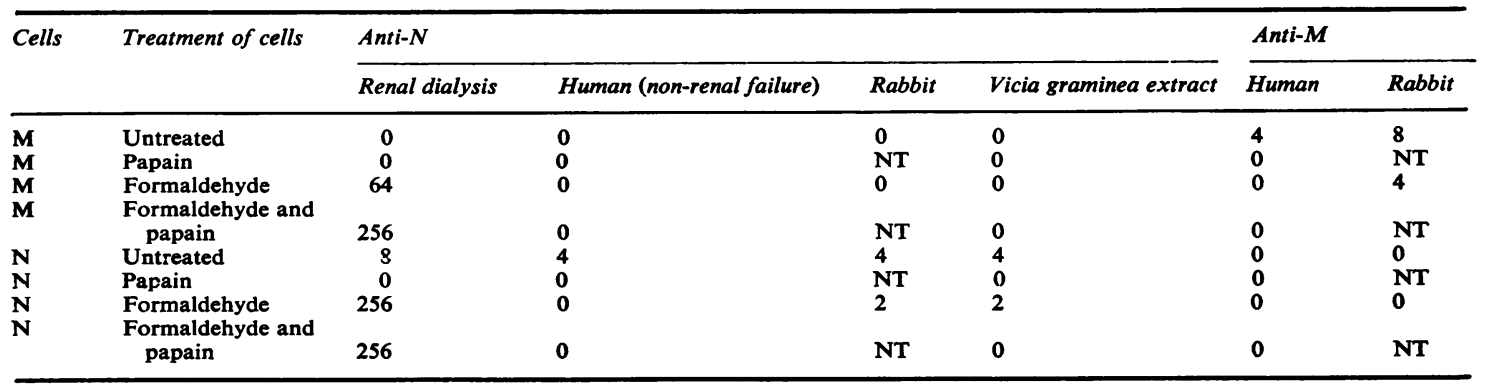

Figures are reciprocal titres of agglutination tests on slides at room temperature.

$\mathbf{O}=$ no agglutination; $\mathrm{NT}=$ not tested owing to non-specific agglutination of papainised cells by rabbit sera. 
Table $2 M N$ groups of 51 renal dialysis patients with anti-N

\begin{tabular}{lllllll}
\hline Group & Series of: & & \multicolumn{2}{c}{ Total } & Expected (Race and Sanger, 1975) \\
\cline { 2 - 6 } & Howell and Perkins (1972) & Harrison et al. (1975) & McLeish et al. (1975) & Our study & \\
\hline M & 4 & 7 & 2 & 9 & 22 & $14 \cdot 33$ \\
MN & 5 & 6 & 3 & 8 & 22 & $25 \cdot 45$ \\
N & 3 & 2 & 1 & 1 & 7 & $11 \cdot 22$ \\
Total & 12 & 15 & 6 & 18 & 51 & 51 \\
\hline
\end{tabular}

$x^{2}=6 \cdot 16 ; \mathrm{P}<0.05,2 \mathrm{DF}$

almost no effect after 24 hours at $4^{\circ} \mathrm{C}$. At room temperature a concentration as low as $0.002 \%$ was sufficient to induce the new specificity in $\mathbf{2 0}$ hours.

\section{Discussion}

This remarkable change wrought in the red cells by very low concentrations of formaldehyde appears to be responsible for the production of the powerful agglutinins with anti- $\mathrm{N}$ specificity observed in patients on home dialysis. It was noted in the original study (Howell and Perkins, 1972) that visible accumulations of red cells remained in the dialyser after flushing through, and it is easy to see how these cells might be changed by the formaldehyde and subsequently washed back into the patient's veins two or three times a week. The formaldehyde is dialysed away before re-use so any concentration from $2 \%$ down to zero may exist in the machine.

Only the use of the cells chemically altered in vitro has revealed the power and true specificity of the agglutinin. A recent publication has shown similar results with a small number of sera (Boettcher et al., 1976), but the concentrations of formalin used were too high to produce fully the change we describe. The nature of the change is not yet known but the results of the enzyme experiments indicate that it is not modification of the $\mathrm{M}$ or $\mathrm{N}$ antigen per se, for it occurs even if they are removed by papain treatment. What relation the new antigen $\mathrm{N}_{F}$ bears to the MNS system is not clear but it may be related to some substance basic to the MNS system as $\mathrm{H}$ is to the ABO system.

When the frequencies of the MN groups of renal dialysis patients with anti- $\mathrm{N}$ are compared with the frequencies for Northern European populations (Race and Sanger, 1975), an excess of $M$ is revealed (Table 2). We do not, of course, know the racial origin of all the patients, but the figures suggest that possession of the $\mathrm{N}$ antigen may make a person less likely to respond to the $\mathrm{N}_{\mathrm{F}}$ antigen.

It seems, therefore, that patients on home dialysis should be screened for antibodies and the thermal range and characteristics of any agglutinin investi- gated. Kidney donors can be $\mathrm{MN}$ typed very rapidly, and if a kidney from an $\mathrm{N}$ positive donor must be given to a recipient with anti-N, particular care should be taken to warm the graft immediately before the vascular anastomosis is made.

The problem could, of course, be prevented if the use of formaldehyde to sterilise home dialysers were avoided, although already some $10-15 \%$ of patients awaiting renal transplantation may be expected to have this powerful antibody in their sera. It has been observed, however, that the antibody disappears after successful renal transplantation (Howell and Perkins, 1972), so it is likely to disappear in time if patients can avoid further antigenic stimulation by formaldehyde treated cells.

We are indebted to $\mathrm{Dr} \mathrm{B}$. W. Otridge, Mr R. A. Crossley, and $\mathrm{Mr} \mathrm{T}$. A. Morris for collecting and screening the sera, and to Dr A. J. Ralston and Dr P. A. Ackrill, under whose care the patients are, for their co-operation.

\section{References}

Bangham, A. D., Flemans, R., Heard, D. H., and Seaman, G. V. F. (1958). An apparatus for microelectrophoresis of small particles. Nature (London), 182, 642-644.

Belzer, F. O., Kountz, S. L., and Perkins, H. A. (1971). Red cell cold autoagglutinins as a cause of failure of renal allotransplantation. Transplantation, 11, 422-424.

Bird, G. W. G., and Wingham, J. (1973). The action of seed and other reagents on En(a-) erythrocytes. Vox Sanguinis, 24, 48-57.

Boettcher, B., Nanra, R. S., Roberts, T. K., Mallan, M., and Watterson, C. A. (1976). Specificity and possible origin of anti- $\mathrm{N}$ antibodies developed by patients undergoing chronic haemodialysis. Vox Sanguinis, 31, 408415.

Harrison, P. B., Jansson, K., Kronenberg, H., Mahony, J. F., and Tiller, D. (1975). Cold agglutinin formation in patients undergoing haemodialysis. A possible relationship to dialyser re-use. Australian and New Zealand Journal of Medicine, 5, 195-197.

Howell, E. D., and Perkins, H. A. (1972). Anti-N-like antibodies in the sera of patients undergoing chronic haemodialysis. Vox Sanguinis, 23, 291-299. 
McLeish, W. A., Brathwaite, A. F., and Peterson, P. M. (1975). Anti-N antibodies in haemodialysis patients. Transfusion (Philadelphia), 15, 43-45.

Race, R. R., and Sanger, R. (1975). MNSs frequencies in white people. In Blood Groups in Man, by R. R. Race and $R$. Sanger, 6th edition, pp. 93-96. Blackwell, Oxford.

\section{The September 1977 Issue}

\section{THE SEPTEMBER 1977 ISSUE CONTAINS THE FOLLOWING PAPERS}

\section{Editorial}

Training of pathologists in countries belonging to the European Economic Community M. G. RINSLER

Histopathological occurrence and characterisation of calcium oxalate: a review A. J. CHAPLIN

$\beta$-glucuronidase activity of lymph node imprints from malignant lymphomas and chronic lymphocytic leukaemia G. A. PANGALIS, X. YATAGANAS, AND PH. FESSAS

HBsAg, chronic lymphoproliferative disorders, and cirrhosis of liver R. HEIMANN, M. B. RAY, AND V. J. DESMET

Lymphocyte tubular structures in rheumatoid arthritis ANTOINE DRYLL, PAULE CAZALIS, AND ANTOINE RYCKEWAERT

Evaluation of a standardised assay for the measurement of antibodies to double-stranded (native) DNA P. DAVIS, M. BURRINGTON, A. R. MORGAN, AND A. SAETRE

Radioimmunoassay of capsular polysaccharide antigens of groups $\mathbf{A}$ and $\mathbf{C}$ meningococci and Haemophilus influenzae type $\mathrm{b}$ in cerebrospinal fluid HELENA KÄYHTY, P. HELENA MÄKELÄ, AND ERKKI RUOSLAHTI

Use of antiserum agar plates for serogrouping of meningococci AULIKKI SIVONEN, O-V. RENKONEN, AND J. B. ROBBINS

Taxonomy of Acinetobacter: the usefulness of $\beta$-Dxyloside xylohydrolase for strain differentiation W. HANSEN, E. SCHOUTENS, AND E. YOURASSOWSKY

Subacute bacterial endocarditis due to Actinobacillus actinomycetemcomitans. Report of a case with a review of the literature J. VANDEPITTE, H. DE GEEST, AND P. JOUSTEN

Direct immunofluorescence in the diagnosis of toxoplasmic lymphadenitis ROBERT M. MATOSSIAN, VICTOR H. NASSAR, AND AHMED BASMADJI
Two cases of monoclonal immunoglobulins with antistreptolysin activity: clinical and laboratory study F. A. TH. LUSTERMANS AND F. KLEIN

Abnormal lipoproteins in multiple myelomatosis A. AVGerinOS, PH. SKLIROS, J. PYROVOLAKIS, AND D. STATHAKOS

IgG myeloma presenting as ulcerative colitis $\mathbf{M}$. $\mathbf{R}$. HAENEY, I. N. ROSS, R. A. THOMPSON, AND P. ASQUITH

Acquired cystic disease of the kidneys: a hazard of long-term intermittent maintenance haemodialysis M. S. DUNNILL, P. R. MILLARD, AND D. OLIVER

Carcinoembryonic antigen in thyroid disease $\mathbf{J}$. ECONOMIDOU, P. KARACOULIS, O. N. MANOUSOS, E. MANESIS, A. KYDONAKIS, AND D. A. KOUTRAS

Standardisation of a simple method for the determination of antithrombin activity ALBERTO FRIGOLA

Diagnosis of $\alpha$-thalassaemia trait from Coulter Counter ' $S$ ' indices U. M. HEGDE, J. M. WHITE, G. H. HART, AND G. W. MARSH

Use, and abuse, of the telephone in clinical laboratories: a simple solution A. R. HENDERSON

\section{Technical methods}

Specificity control in solid-phase enzyme immunoassay for $\mathrm{Hb}_{\mathrm{s}} \mathrm{Ag}$ by one-step in situ blocking with human anti-Hb J. KACAKI, G. WOLTERS, L. KUIJPERS, AND A. SCHUURS

An improved method for handling tissues for immunofluorescence JOHN KLASSEN AND MEREILLE KHOURY

Application of a modified Attwood's stain to the study of decalcified bone sections S. PUTNS AND D. J. DESA

Letters to the Editor

Book reviews

Copies are still available and may be obtained from the PUBLISHING MANAGER, BRITISH MEDICAL ASSOCIATION, TAVISTOCK SQUARE, LONDON WClH $9 \mathrm{JR}$, price $£ 3 \cdot 00$, including postage 